\title{
Vol.1, No.1
}

\section{Spring 1990}
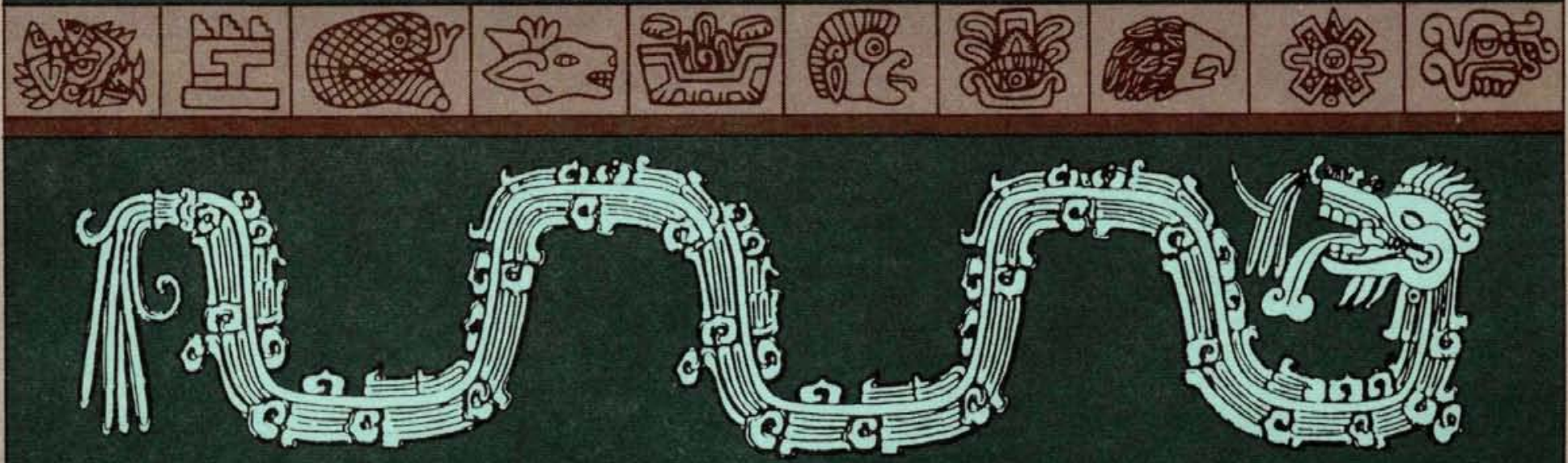

INCLUDED IN THISISSUE

Big Man, Big Heart?

Ancient Winds of Change

Activities in Classic Households,

Maize Storage among the Puuc Maya

Obsidian Artifacts from Tikal, Guatemala

Household Archaeology at Cerén, El Salvador

Maya Writing for the Verb "To Record"

Special Section: Rethinking Mixtec Codices

Search for History in Mixtec Codices

Mixtec Landscape Perception and Settlement Patterns

Performance and Structure of the Mixtec Codices

Poetics and Metaphor in Mixtec Writing

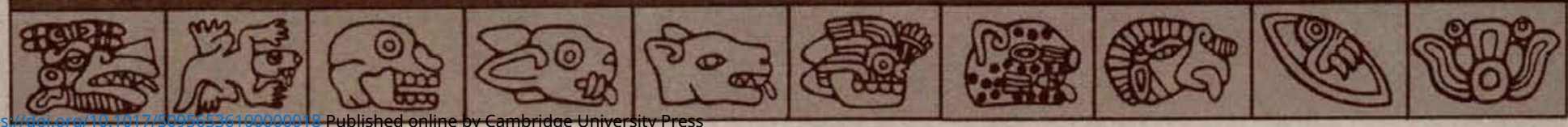




\title{
Ancient \\ Mesoamerica
}

\author{
Co-Editors \\ William R. Fowler, Jr. and Stephen D. Houston \\ Department of Anthropology, Vanderbilt University
}

\begin{tabular}{|c|c|}
\hline \multicolumn{2}{|c|}{ Editorial Board } \\
\hline $\begin{array}{l}\text { Frances F. Berdan, California State University, San } \\
\text { Bernardino }\end{array}$ & $\begin{array}{l}\text { Linda Manzanilla, Universidad Nacional Autónoma de } \\
\text { México }\end{array}$ \\
\hline Ronald L. Bishop, Smithsonian Institution & Juan Pedro Laporte Molina, Universidad de San Carlo \\
\hline $\begin{array}{l}\text { Warwick M. Bray, Institute of Archaeology, University } \\
\text { of London }\end{array}$ & $\begin{array}{l}\text { Jeffrey R. Parsons, University of Michigan } \\
\text { Esther Pasztory, Columbia University }\end{array}$ \\
\hline Lyle R. Campbell, Louisiana State University & David Pendergast, Royal Ontario Museum \\
\hline Pedro Carrasco, State University of New York, Stony & Hanns ]. Prem, Universität Bonn \\
\hline $\begin{array}{l}\text { Brook } \\
\text { Noemi Castillo Tejero, Instituto Nacional de }\end{array}$ & $\begin{array}{l}\text { Robert ]. Sharer, University of Pennsylvania } \\
\text { Pavson D. Sheets, University of Colorado }\end{array}$ \\
\hline Antropología e Historia, México & Michael E. Smith, Loyola University, Chicago \\
\hline George L. Cowgill, Brandeis University & Michael W. Spence, University of Western Ontario \\
\hline Arthur A. Demarest, Vanderbilt University & nald Spores, Vanderbilt University \\
\hline ichard A. Diehl, University of Alabama & II, Clark University \\
\hline avid C. Grove, University of Illinois & Emily Umberger, Arizona State University \\
\hline Norman Hammond, Boston University & Phil C. Weigand, Museum of Northern Arizona \\
\hline Kenneth G. Hirth, University of Kentucky & David Webster, Pennsylvania State University \\
\hline Barry L. Isaac, University of Cincinnati & Daniel Wolfman, Museum of New Mexico \\
\hline Stephen A. Kowalewski, University of Georgia & Elias Zamora Acosta, Universidad de Sevilla \\
\hline
\end{tabular}

Ancient Mesoamerica is a semi-annual international forum for the method, theory, substance, and interpretation of Mexoamerican archaeology, art history, ethnohistory, historical linguistics, and related fields. The journal will publish original research papers, theoretical articles, and substantive reports of field research.

Editorial Office

Ancient Mesoamerica, Editorial Office, Vanderbilt University, P.O. Box 6307-B, Nashville, TN 37235, USA. Telephone: (615) 343-6123 (Fowler) or 6122 (Houston). Facsimile: 615-343-5555. Bitnet: ANCMESO@VUCTRVAX.

Publishing, Subscription, and Advertising Offices

Cambridge University Press, 40 West 20th Street, New York, NY 10011, USA; The Edinburgh Building, Shaftesbury Road, Cambridge CB2 2RU; England.

Subscription Information

Ancient Mesoamerica is published biannually. Annual subscription rates for Volume 1 (1990): Institutional, US $\$ 80.00$ in North America, UK $£ 49.00$ elsewhere; Individual, US $\$ 40.00$ in North America, UK $£ 24.00$ elsewhere.

\section{Copyright (c) 1990 Cambridge University Press}

All rights reserved. No part of this publication may be reproduced, in any form or by any means, electronic, photocopying or otherwise, without written permission from Cambridge University Press.

Photocopying information for users in the USA: The Item-Fee Code for this publication $(0956-5361 / 90 \$ 5.00+.00)$ indicates that copying for internal or personal use beyond that permitted by Sec. 107 or 108 of the U.S. Copyright Law is authorized for users duly registered with the Copyright Clearance Center (CCC) Transaction Reporting Service, provided that the appropriate remittance of $\$ 5.00$ per article is paid directly to: CCC, 27 Congress Street, Salem, MA 01970 . Specific written permission must be obtained from Cambridge University Press for all other copying. Contact the ISI Tearsheet Service, 3501 Market Street, Philadelphia, PA 19104, for single copies of separate articles. 